\title{
Missing Dimensions in \\ Contemporary Islamic Movements
}

\author{
Țāhā J. al 'Alwānì
}

\section{Opening Remarks}

This paper will examine dimensions that seem to be absent, whether totally or partially, from the thought and practice of certain contemporary Islamic movements in the Muslim world, many of which may be viewed as extensions of the liberation movements that played significant roles in maintaining the ummah's identity at the turn of the twentieth century. We will address these movements and remind them, for "remembrance does the faithful a world of good" and "wisdom is the pursuit of the faithful; wherever it is found it should be cherished."

Since God created Adam, people have fallen into two categories: those who perform their roles according to the teachings of revelation and those whose roles originate from their own ideas, desires, and views or those that have been passed down from their ancestors. The first type sees history as the outcome of conflict between humanity and nature. In response to the latter, the true religion-Islam-has been the indispensable sine qua non for correcting humanity's basic assumptions, rebuilding its vision, helping it to find peace of mind, and providing it with answers to quintessential quesions.

The use of Islam as the foundation for both thought and practice is the force that drives activist Muslims. In the Qur'an, God revealed a perfect text that responds to questions of existence at all levels. ${ }^{1}$ Moreover, God has linked the Qur'an's totality and all-encompassing explanatory nature to the responsibility of witnessing that, after the Prophet, was passed on to the ummah. ${ }^{2}$ Through the testimony of the Prophet and of the ummah, God

TTăhä J. al 'Alwăni is a member of the Fiqh Academy of the Organization of the Islamic Conference, chairman of the Fiqh Council of North America, and president of the Internationa! Institute of Islamic Thought in Herndon, Virginia. This paper has been summarized by Yusuf Talal DeLorenzo, IIIT Research Department, after its translation from the original Arabic by Mohammed Akram Saadeddin, Director, Centre for Languages and Pre-University Academic Development (CELPAD), International Islamic University, Malaysia. The translator wishes to acknowledge the technical assistance of David Ellis and Adnan Holden. The original paper will pe published by the IIIT in Arabic as a 105page monograph entitled $A b^{\prime}$ ad Ghä'ibah 'an Fikr w'a Mumärisāt al Harakāt al Islamiyah al Múāsirah. 
will certainly cause His purposes to prevail. ${ }^{3}$ We define this witnessing as a consciously responsible type of witnessing that has its own economic, social, and intellectual characteristics based on a specific societal order, on the one hand, and a specific scientific and methodological order on the other. Our responsibility in witnessing, then, is much greater than we have envisaged or put into practice in the past.

Certain dimensions that are absent from our perspectives and practices may be uncovered by weighing them against the objectives manifest in the repsonsibility of witnessing. ${ }^{4}$ This process makes the issue of reform and change a composite, as opposed to a simple, one. Moreover, both factors require an awareness that must be "methodological" and that examines all dimensions at the levels of both theory and application. In this way, we may gain an understanding of the agents that affect change and generate deviation and the resulting crises.

The factors affecting the variables in the current state of affairs in Muslim societies are not regional-they are global. The nature of this crisis springs from the current level of interaction among nations and peoples that has been generated by the contemporary information explosion. A proper understanding of this phenomenon is essential if we are to comprehend contemporary developments. Not only have we adopted "foreign" systems of government, as well as economic and social institutions, but these have contributed to the transformation of our worldview to such an extent that it has now become recast largely in the image of the dominant western paradigm. And, as we know, any epistemological paradigm contains within it the potential to overwhelm others. This is the real danger, and has come to be known as the intellectual or cultural invasion.

There are only two possible reactions to this situation: Either one aligns oneself with the dominant system (or, to use Ibn Khaldūn's term, mutaghallib), or one rejects the dominant system entirely. Choosing the first option starts with a mode that might be called "approximation." A good example of this is how western democracy is sometimes "approximated" to Islamic shürä (mutual consultion) despite significant differences between the two civilizational and epistemological paradigms. Another example is the approximation of social justice to socialism, regardless of the fact that socialism is rooted in class conflict while Islamic social justice is rooted in the equitable distribution of wealth between the individual and the community by means of zakat, inheritance, and the prohibition of hoarding. All in all, such attempts are the result of the epistemological influences that pervade our contemporary consciousness and culture. Those who choose rejection do so through contrasting our heritage with that of the dominant one, an undertaking that serves only to glorify our past without examining it critically or analytically. In fact, our heritage lacks the wherewithal to overcome its own crises. Otherwise, we might have maintained our position as the dominant civilization. 
in clear contravention of the postulate that a divine text, when projected onto a historical or existential reality, is not meant to justify it but rather to change it or improve on and reform it. Through our selective interpretations of the divine texts, we lost touch with the purpose of witnessing to that which has been entrusted to us by God. It follows that we forfeited our relationship with God. How, then, can we expect Him to unite our hearts and souls as He did before we severed our links with the requirements of witnessing? Will it suffice, given the current state of affairs, to retrieve the fruits of ijtihad sown in the early centuries of Islam, or is there a qualitatively different reality that requires a new ijtihad? How do we bring about the appropriate milieu for this new ijtihad? To what extent does the changing state of affairs generate new impasses? What are the problems, if any, that cannot be resolved through analogical reasoning? Such problems would inevitably require fresh recourse to the totality of the divine revelation.

\section{Towards a Comprehensive View of Revelation and the Existential}

What is the basis of the view that propounds quantitative and qualitative change in the relationship between revelation and the existential? Ibn Khaldūn explained the foundations of human civilization in terms of environmental factors and within the framework of pastoral, agricultural, and labor-intensive societies - the society of natural economy - by means of the factors that affect progress and decline: birth, maturity, and old age. Contemporary western studies have brought home to us an understanding of the foundations of synthetic civilization, where humanity has gone before the era of natural civilization, by exercising control over natural phenomena. The quantitative aned qualitative changes in the nature of human civilization have engendered a new positioning in human thought. Humanity's view of itself, its relationship with the natural universe and society, and its system of values and ethics have all undergone major change.

A new quantitative logic is in the process of taking over the world, not because the world has progressed to this technological level, but because the dominant civilization, armed with its scientific progress, has overshadowed all other epistemological orders and gained control over many of our mental and perceptual processes. The most significant change to occur is that our perceptual processes are no longer confined to rational premises, observation, intuition, and experience, for, beginning with the natural sciences and then with the social sciences and the humanities, these have been subjected to systematic doubt and criticsm.

Some confusion has arisen over the distinction between the development of human societies in the material sense and their qualitative changes 
in the historical sense. In our context, qualitative change refers to the historical and not the materially developmental. This view was embedded in the writings of both Ibn Batuttah (1302-77) and Ibn Khaldūn (1332-1406). The former linked natural phenomena with social phenomena, while the latter merged them in the context of birth, maturity, and atrophy in his early attempts to systematize the philosophy of history. The purpose of these studies underscores the need for a dynamic, as opposed to a static, understanding of human societies. Static society connotes stagnation, while a dynamic society connotes constant change. Ibn Khaldūn ranked these two concepts as equal and called them "the constant" and "the variable" in his reading of the three historical stages of human civilization within the natural social order.

We may now consider, in particular, the problems presented by the contemporary world and how Muslim reformers deal with them. Serious problems have existed for many centuries. If we were to draw a detailed diagram of the types of problems addressed by earlier Muslim reformers, it would become clear that most were issues striking at the roots of the intellect, be they jurisprudential, historical, political, social, economic, or even linguistic or philosophical. Our civilizational delcine, to quote Ibn Khaldūn, did not issue from a single shortcoming but was rather the result of a multidimensional failure.

\section{Collective Ijtihad}

In terms of intellectual reform, there were some individuals who began to reform the field of Qur'anic interpretation by weeding out the fabrications, legends, and myths that had been allowed to permeate it. Others dealt with the nature of political tyranny and the rules of government. Examples of such piecemeal reform abound. However, scholars whose research may contribute to reforming our thought at the theoretical level have not yet addressed the issue of the ummah's reform, and it is this void that has led us to call for collective ijtihad. Certainly, one of the aims of IIIT is the coordination of a variety of academic initiatives in order to produce a collective outcome that responds to contemporary problems.

Reforming theory or methods of thought as a prelude to reforming practice is not confined only to studying how past scholars approached the Qur'an and the Sunnah and the factors that condition ijtihad. In fact, these factors have changed immensely. Some researchers perceive things in terms of their multiplicity, polarity, or unity, whereas others deal with material through descriptive interpretation or epistemological analysis. Collective ijtihad, through encompassing all elements of today's existential reality by various epistemological methods, will also address the mistaken notion that economic reform will solve all of our problems. Our experience at IIIT, consisting of approximately ten years of collaborative work on the intellectual plane, has revealed to us the depth and breadth of 
the crisis and has convinced us further of the need for collective effort and intellectual collaboration. Many organizations and movements set out under the impression that they have been called upon to reform the ummah. This simplistic notion carries deep within it the delusion that the organization or movement is somehow the sole possessor of the truth. The results of such thinking are clearly counterproductive and of no real benefit.

Before summarizing what I term the crisis of contemporary Islamic movements, I will reiterate certain basic characteristics of the ummah that must be considered when surveying the dimensions missing from contemporary reform and revival movements. In brief, these are: a) the Qur'an's sovereignty and haymanah; b) the Islamic discourse's universality; c) an accommodating and merciful Shari'ah; d) the finality of prophethood; and e) the integrated and complementary reading of revelation and the realexistential. $^{14}$

The distinctive features in the crisis of contemporary Islamic movements and the dimensions that are absent from their agendas are:

1. Due to their acquisition of a predominantly political party mentality, many of these movements are isolated from the ummah and incapable of carrying out collective action within the framework of the ummah as a unified whole. For this reason, it has been relatively simple to isolate and neutralize them.

2. They make the common mistake of confusing revealed scripture with human interpretation.

3. This confusion of the divine and the human has led some to claim that they are in sole possession of the truth. By projecting the sanctity of the Islamic text onto their own ideas and ijtihad, they have sought to co-opt and credit to themselves historical achievements by asserting that they represent the only valid extension of those historical realities.

4. Some individuals have deluded themselves into believing that as long as they have the Qur'an and the Sunnah in hand, there is no need to engage in the necessary effort or to achieve the intellectual competence required for ijtihad. As a result, they do not gain a true understanding of Islam or link the spirit of its text to the letter of real situations. Their organizations, established without reference to the world of ideas, consist of a haphazard mixture of selected, adapted, and grafted notions from history and their own experience. The resulting inability to meet their organization's daily requirements or to control its direction through the generation of sound and innovative ideas has made their confusion inevitable. 
5. Certain resulting misconceptions and intellectual oversights have mired the ummah in organizational details and, at another level, have mired Islam in details of a supposed Islamic political order.

6. Despite their continued emphasis on adherence to Islamic texts, many movements have failed to define suitable agendas that represent their consciousness of Islam's distinguishing creed and practice. Such an agenda will constitute the cornerstone of any comprehensive Islamic discourse designed to deliver its message and carry it to its logical conclusion successfully.

God is the Lord of all people, whether they are European, American, African, or Asian. He has promised and prepared the way for a new universalism that stands in contrast-owing to its comprehensiveness-to the pervasive western hegemony now dominating the world. This universalism is not that of fanaticism or of a call emanating from a historical or geographical specificity in opposition to the West, but rather a universalism of mercy both for us and for the West, on an equal footing and for the whole world.

In order to explain this in more detail, the following points may be germane:

1. First, its raison d'être is the world's desperate need for solutions to its social, ecological, intellectual, economic, and political crises. The crisis of the dominant western civilization is not far removed from that of the Muslim ummah.

2. Universalism is the only concept capable of responding to western hegemony.

3. When we start working towards universalism, we do so in response to our commitment to stewardship over the Earth and the responsibility of witnessing. These are not merely favors that we do for others, for the measure of our commitment to our responsibilities before God will determine the measure of our freedom, particularly as Muslims. If we are truly committed, we will rid ourselves of our own crises. What we do for others will reflect on us, and God has ordained that we carry His Message and be His witnesses to humanity.

4. The present civilizational order, which is based on conflict and the culture of power, finds it hard to apply ethical practices unless they are devoid of effective reformational power. You may pray to God for what you want, but you cannot act economically or socially in a way that contravenes the interest of those in power. Citizens may proselytize for Jesus Christ as they see fit, but when one goes beyond that, he/she is classified as a fundamentalist, fanatic, or extremist. 
What should be done to actualize the interaction between the universality of Islam and the West? Despite all of the historical, religious, and other difficulties, this goal can be attained by pursuing two major courses of action. First, western civilization is living through a crisis in the aftermath of analytical deconstruction. Only the Qur'an can bring about reconstruciton. It is therefore our urgent responsibility to build the closest of relationships with all schools of western analysis, regardless of their trends or directions. Second, we must give all possible support to the Islamization of Knowledge in the natural sciences and the reconstruction of the humanities and the social sciences. The development of these sciences in their universal unity will provide the impetus for westerners to open their minds to our methodology so that they may explore and eventually make use of it. Third, this will enable contact to be made with the western world and its elite so that dialogue can take place within a scientific methodological framework where we need only to prepare ourselves with a conceptual awareness of the Qur'an in order to contribute.

We now return to the Islamic movements and examine their capacity to comprehend and shoulder their responsibilities. Most Islamic movements have bound their visions and ideas to past historical realities, have entrenched their own reality in the past, and therefore search the past when trying to find a solution to a given problem. When they project that historical reality onto their present reality, they do so in a static manner that pays little, if any, attention to the characteristics of the Qur'anic text and, in particular, to its universal nature. They confine the Qur'an and the Sunnah to the limitations prescribed by earlier generations and to an incomplete methodological and epistemological framework based on questionable histories and biographies in need of further documentation and scrutiny. Their logic does not allow them to analyze these frameworks or study them from within in order to understand and compensate for human action, the variables of time and place, and the laws of historical change.

The crisis of the West is one of deconstruction unable to reconstruct, for it has excluded the concepts of divinity, transcendence, and revelation. The crisis in Islamic circles is quite clear when we consider the flawed methodology employed to deal with a far-reaching heritage. Because contemporary Islamic movements fail to effect change through an Islamic epistemological methodology, they a) resort to the violence of "infidelization," b) cling to the letter of the early Islamic historical experience, c) defer to the metaphysical while neglecting the teachings of Islam related to interaction among the divine, humanity, and the universe, and d) seek to gain power in order to introduce change (by legislating sovereignty to God) through their own curatorship or that of a jurisprudent, while trying to appease Him by a cosmetic implementation of the Shari'ah, the penal code, and the hudüd. Within the context of this oversimplification, which is in contravention of the universal nature and prin- 
ciples of Islam, and within the context of this gross trivilization of Islam, political agendas and movements are established by leaders who then seek to support their claim that they alone represent and speak for (and in the name of) Islam.

The world is convinced that Islamic movements seek to change all forms of government and political orders, even those orders within which they work and from which they derive their legitimacy. According to popular wisdom, they seek to change democratically inclined, pluralistic liberal systems, whether restricted or unrestricted. For their part, Islamic movements see themselves as the most deserving of and the most entitled to Islamic legitimacy and thus as the best of all parties.

In pactice, these parties seem preoccupied with trying to embarrass other parties, especially on points of Islamic belief and practice, and are unable and unwilling to compromise with others. On issues of freedom, they are clearly opposed to liberal concepts of plurality. Their opposition to other parties and movements is based on a denial of all others' legitimacy. Such an attitude has caused them to become mesmerized by the notion of acceeding to power within the geographical circles in which they live. They ignore those concepts associated with universalism, an oversight that leads directly to their failure to consider the methodologies needed to achieve them and to deal with the requirements, mechanisms, instruments, and features that should become prominent in all aspects of Islamic discourse. For them, success is related directly to power, and universalism is a luxury that may be indulged in after power has been consolidated. Clearly, this type of thinking must be rectified.

Islamic movements have assimilated certain Islamic objectives and purposes, just as they have assimilated certain aspects of the Islamic form, but only within a limited conceptual framework. They have not been able to construct a paradigm that links those objectives with the laws and ways of social change in society. Consequently, they have restricted themselves to conducting campaigns designed to attract and recruit new members via $d a^{w} w a h$ and other means to bolster their membership. In their experiential memory, change is linked with the creation of an extremely large jama $\bar{a}^{\prime} a h$. Moreover, the laws of social and historical development or the norms of cultural and intellectual change and their correlatives are of no concern to them. Many of their leaders feel that scholarship and knowledge are beneath their dignity and classify these activities as contrary (or nearly so) to belief. Some have even sought rulings from the Shari'ah against people with new ideas.

Fortunately this phenomenon is coming to an end. Although many attempts have been made to overcome this situation, most have fallen short of what is required. Attempts at reforming $u s \underline{u} l$ al fiqh, for example, cannot solve the impasse of connecting definitive scriptural texts with the real-existential. When things get to this stage, the idea of assuming power becomes a spark of light, a solution for or a way out of the crisis that intel- 
lectual efforts fail to address. The assumption of power then becomes a goal towards which all efforts are focused and, when achieved, exerted to maintain. The underlying concept is simple: since thought has failed, why not use the stick?

The Islamic discourse addressed to humanity by the Messenger of God is clearly universal. As such, it will never be left behind by historical developments. If humanity is now progressing towards univeralism, it is impossible for the Islamic discourse to retreat to a state of regionalism, nationalism, or ethnicism. Universality, in which mankind is unified within an overall framework of common values based on transcendent absolutes, represents an area of progress governed by its own conditioning factors.

In his exegetical work, Imām Fakhr al Din al Rāzī (d. 606 A.H.) reports on the authority of al Qaffāl that the jurisprudents' division of the world into the "Land of War," the "Land of Islam," and the "Land of Allegiance" is no longer valid. That was in the fifth Islamic century. Al Rāzi suggested that it would be preferable to divide the world into the "Land of Islam" and the "Land of the Call to Islam" and to redefine the division of humanity into the Muslim ummah and non-Muslim nations by classifying humanity into ummat al ijäbah (the respondent nation of Muslims) and ummat al da'wah (nations to be called to Islam). The ideas of those imams, particularly of al Shäshī, who conveyed the message of Imām al Shăfi'i to Imām Ibn al Mahdī, a scholar of the third century A.H., were closer to the sources of Islam and more acquainted with its evidence. Furthermore, Ibn Mahdi was closer to understanding universalism and perceiving it than are the leaders of contemporary Islamic movements, who remain ignorant of Islam's universality and restrict it on the basis of closed historical and regional specificities. The latter still divide humanity according to its intellectual, cultural, and psychological worldview into East and easterners and West and westerners, and classify people within the same territory into sects and denominations.

The absence of universality has inflicted several intellectual and methodological casualties on the Muslim mind. If Islamic movements had realized this missing dimension earlier, ideas of apology, reconciliation, approximation, emulation, and confrontation, all of which are the most prominent features of recent Islamic thought, would not have emerged. Secularist factions call for universalism within the framework of dependency and surrender to western hegemony, which is diametrically opposite to our call and a stark departure from the Islamic ideal.

The world's crises have become intertwined, universal in nature, and thus require universal solutions. One country's (or people's) crisis is no longer restricted to local or intrinsic factors. The economic, ecological, strategic, political, and cultural interaction produced by the information explosion has transformed particularistic civilizational orders into constitutive parts that now form one universal and global structure, irre- 
spective of whether it is produced by the will of the people and their predictions of a universal future or by the logic of a dialectical interaction that does not allow any territory or people to remain isolated from its reach.

In Foreign Affairs (1993) Samuel P. Huntington discusses conflict among civilizations and postulates that the coming decades will witness a civilizational conflict that will be the last stage in the emergence and development of conflict within the modern world. He points out that nonwestern nations and governments, which before were no more than targets for the western colonizer, have now become a driving force and an added problem to the West. In his projections, he says that the world of the future will be formed via the interaction of seven civilizations: western, Confucian, Japanese, Islamic and Hindu, Selucid Orthodox, and Latin American. To these may be added African civilization. He classified Islamic civilization into Arab, Turkish, and Malay (ignoring Persian, Indian, and other Islamic civilizational areas) and divided western civilization into European and American. In addition, he stressed the essentiality of civilizational differences and underscored the influence of religious differences in the inevitability of civilizational conflict. In his view, religious difference will make this conflict the longest and the most violent.

Although Huntington focused on several significant civilizational phenomena worthy of study, what he omitted betrays a certain naivety and lack of understanding of Islam, its culture, and civilization. Clearly, his opinions are the result of his conventional orientalist perspectives and western background, with its tradition of conflict and rejection. These factors predispose him to view other civilizations, religions, and cultures as adversarial and rejectionist elements that challenge western civilization. In addition, it seems that he has been reading the historical maps of those civilizations as though we were living in the fifteenth century. It is almost as if he did not consider the technological revolution and its consequences or the information explosion and what it has produced. If he had paid sufficient attention to all relevant factors, he might have reached different conclusions and would have realized that his projection may come true if the world does not find the proper ground for unity within the framework of an open civilizational order. Such an order must be based on common-not idiosyncratic, religious, regional, or nationalistic-values that stand for absolutes respected by all of humanity.

Roger Garaudy, who has studied Islam and understands its characteristics, does not foresee a civilizational conflict, but rather a dialogue that prepares the ground for universalism. In the introduction to his The Dialogue of Civilizations (p. 17), he stressess that what researchers term the "West" actually originated in Mesopotamia and ancient Egypt. He criticizes the West strongly for its ignorance of Islamic civilization's characteristics and properties in particular and of other civilizations in general. 
He calls upon the West to discover for itself the characteristics of Islamic civilization by pointing out that his individual crisis before converting to Islam was exactly like that crisis of the West, as both are rooted in the same background. It follows that the West's discovery of Islam would allow it to solve its crises. He also gives a practical example for engendering a global cultural revolution that can be summarized as follows:

1. Nonwestern civilizations should be studied by all students at western universities and schools;

2. Philosophical thought will have to be reexamined-meaning that indepth intellectual and philosophical studies should not be underrated in comparison with scientific and technological studies;

3. Attention should be given to aesthetics as a science, and it should be regarded as equal in importance to the technological sciences; and

4. Attention should be paid to futuristic studies with continuous reference to human history.

Although Garudy and others have overcome their crises with western thought through Islam, they have not succeeded in treating their new crisis as Muslims. In other words, they have come to Islam not by inheritance but from a different civilizational and cultural order. An examiner of this new breed of Muslims, which represents the first fruition of our future universalism and combines our heritage with its new heritage, will find much with which to sympathize. But there is a caveat: The light of the new Muslims' potential may fade away and die completely as they plunge deeper into the Islamic heritage, or it may even be drowned in an agnostic ocean of Sufism. As a result, their new situation might not be all that different from their pre-Islamic one. The reasons for this are twofold: a) they may not be able to discover the facts of Islam and its universal characteristics in their entirety in the accumulated Islamic heritage, and b) contemporary Islamic thought, encumbered by restrictions inherited and imposed from the early years of Islam, has been unable to present either itself or those characteristics clearly.

The majority of those who have discovered Islam through the Qur'an believe in it and recognize its importance. However, when they come to the intellectual heritage, which Muslims have transformed into a sacred text parallel to the Qur'an on the pretext that it is an interpretation of the Qur'an and the Sunnah, they discover that much of what they had sought to escape from is also embedded in their adopted faith.

Muslim intellectuals and scholars seem to have forgotten that Imām Shāfiri initially produced his jurisprudence in Baghdad, where he wrote his al Hujjah and read it to such scholars as Ahmad ibn Hanbal, Abū Thawr, and Karabisis. When he left Baghdad for Cairo, he reconsidered 
his jurisprudence in toto and revised all but thirteen questions in the corpus of his work. In other words this great jurist, who lived for only fifty years, produced two different versions of comprehensive jurisprudential thought. Although the differences between the societies of Baghdad and Cairo at that time were not very pronounced-certainly not as significant as those between contemporary Japanese society and those of the Najd or of America-contemporary Muslim scholars insist that modern Muslims must conform to a societal order that is completely different and based on jurisprudential schools founded in the Hijāz or Küfah during the second century A.H. They do not realize what the Islamic concept of universality means in terms of the capacity to encompass different societal orders within the framework of absolute value and not within the framework of perceptual variables of belief that are influenced by innumerable factors.

Constant renewal of the message, carrying it to the people, and witnessing are not Islamic options that the ummah may choose to perform, ignore, or compromise. All Muslims, regardless of the time in which they live, are required to review Islamic discourse continuously and to make it understandable to all people. If they do not shoulder these responsibilities and carry them out successfully, the ummah in its entirety will be held accountable.

The Islamic concepts of "finalty of prophethood" and "witnessing to all humanity" point to the above. If this ummah had remained truly aware of and dedicated to its role and the essence of its mission, would it find itself in the mud in which it is presently mired? If its leaders-scholars, intellectuals, party members, activists, and preachers - were aware of these reponsiblities, would they continue to occupy themselves with matters that are irrelevant to this message and mission?

Prophethood ended with Muhammad, who was entrusted with the tasks of religious revival and societal reform and of delivering the etemal message of peace to humanity. Thereafter, the ummah became collectively responsible for compensating humanity for the fact that no more prophets would be sent. But in spite of all of that, Muslim scholars and intellectuals have become like the prophets of Israel when God made Ṭālüt king:

They said: "How can he exercise authority over us when we are better suited than he to exercise authority, and he is not even gifted with wealth in abundance?" (Qur'an 2:247)

The children of Israel were replaced by the ummah of Muhammad so that humanity might begin to move towards universalism. This began with building "the pivotal ummah" and replacing the concept of "people" in the narrow ethnic sense with that of "ummah," for the final Messenger was sent as "a mercy for all the worlds." 


\section{Endnotes}

1. Qur'an 16:89.

2. Qur'an 2:143.

3. Qur'an 61:9.

4. Qur'an 14:1, 24:40, and 24:35.

5. The author has discussed this phenomena in a lecture entitled: "The Contemporary Intellectual Crisis: A Diagnosis and Suggested Remedy" as well as in a treatise that appeared in Methods of Reform in Islamic Thought.

6. An oft-cited hadith in this context is that the Prophet said: "The last of this ummah can only be reformed by that with which it was reformed at the very beginning."

7. Qur'an 8:63.

8. Qur'an 33:40.

9. This attribute, haymanah, is derived from al Muhaymin, a name of God meaning the All-Observing and the All-Protecting. When applied to the Qur'an, it implies its authority over what had preceded it and what succeeds it. It also implies that it has critically retrieved the heritage of all previous prophethoods and reintroduced them in their authentic form and free from the distortions of addition or omission.

10. Qur'an 5:48.

11. Qur'an 7:157 and 62:2-3.

12. Qur'an 16:92.

13. Qur'an 6:91.

14. For a detailed discussion of these two "readings," see al "Alwānī, "The Islamization of Knowledge: Yesterday and Today," The American Journal of Islamic Social Sciences 12, no 1 (Spring 1995):84-87. 